\title{
Oil, the Global Economy and Tourism
}

\author{
Susanne Becken \\ Lincoln University \\ Potchefstroom, 12-16 Sep 2010
}




\section{Background}

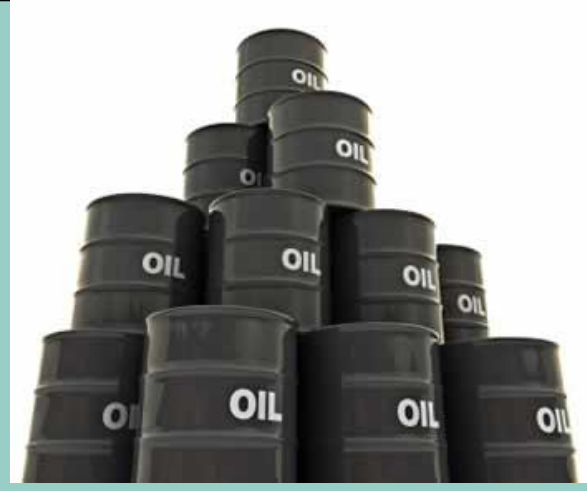

- Tourism inherently dependant on oil

- No substitutes readily available for aviation

- Oil is also an essential input factor into other economic activities (that determine wealth and travel propensity)

- Oil prices have been fluctuating substantially 


\section{Oil prices}

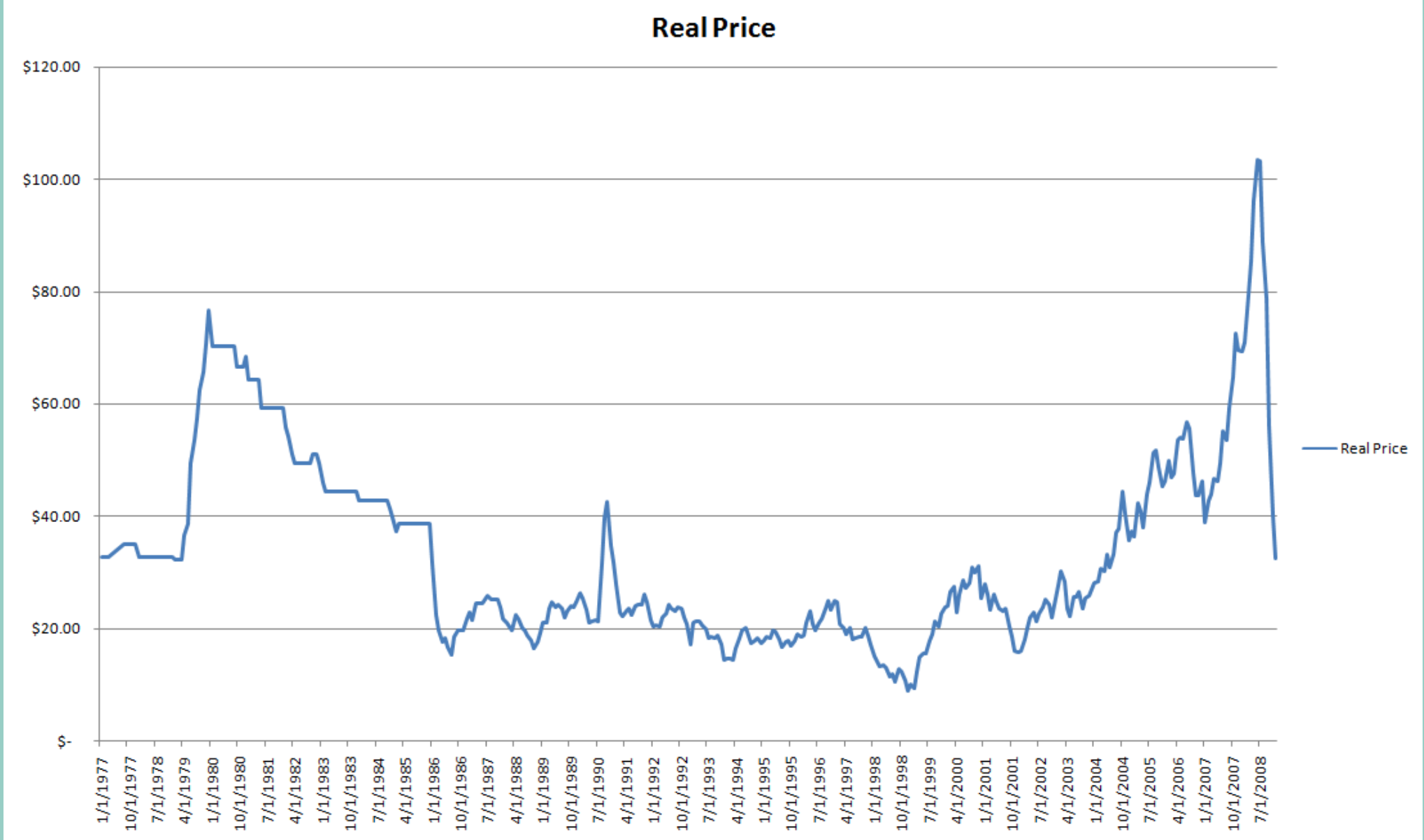

Source: http://www.leetobey.com/2008_12_01_archive.html
Centre for Land
Environment
\& People
A Lincoln University Research Centre.
New Zealand's specialist land-based university 


\section{Methodology}

Four phases:

- Fact finding analysis (2007)

- Importance of oil to parts of the tourism system (2008)

- Impacts of oil price changes on the whole tourism system and the New Zealand economy (2008-09)

- Addressing oil vulnerability (2010). 


\section{Specific components}

\begin{tabular}{|c|c|c|}
\hline Phase & Method & Research Objectives \\
\hline \multirow[t]{3}{*}{1} & Literature Review & $\begin{array}{l}\text { Overview of relationship between oil and tourism, and price } \\
\text { sensitivity of tourists }\end{array}$ \\
\hline & $\begin{array}{l}\text { Stakeholder Interviews } \\
(\mathrm{N}=10)\end{array}$ & $\begin{array}{l}\text { Understand perceptions of oil and possibly supply challenges } \\
\text { held by tourism stakeholders }\end{array}$ \\
\hline & $\begin{array}{l}\text { Campervan Tourists Survey } \\
(\mathrm{N}=1121)\end{array}$ & $\begin{array}{l}\text { Explore tourists' perceptions of oil and reactions to higher oil } \\
\text { prices with respects to travel }\end{array}$ \\
\hline \multirow[t]{4}{*}{2} & Tourism Arrivals Model & $\begin{array}{l}\text { Econometric analysis to relate oil prices to tourist arrivals by } \\
\text { market }\end{array}$ \\
\hline & Elasticity Analyses & $\begin{array}{l}\text { Econometric modelling to understand elasticities of } 18 \\
\text { segments }\end{array}$ \\
\hline & Distance Models & $\begin{array}{l}\text { Econometric modelling to analyse transport and petrol prices in } \\
\text { relation to transport behaviour in }\end{array}$ \\
\hline & $\begin{array}{l}\text { Business Energy Survey } \\
(\mathrm{N}=417)\end{array}$ & $\begin{array}{l}\text { Understand operators' perceptions of energy use and saving } \\
\text { initiatives }\end{array}$ \\
\hline 3 & $\begin{array}{l}\text { Computable General } \\
\text { Equilibrium Model }\end{array}$ & $\begin{array}{l}\text { CGE model to assess effects of changes in oil price on the } \\
\text { economy }\end{array}$ \\
\hline 4 & $\begin{array}{l}\text { Dissemination and } \\
\text { Communication }\end{array}$ & $\begin{array}{l}\text { Engagement with industry and policy makers to inform decision } \\
\text { making and assist energy saving initiatives }\end{array}$ \\
\hline
\end{tabular}

Centre for Land

Environment

\& People

A Lincoln University Research Centre.
New Zealand's specialist land-based univers 


\section{Importance of oil for tourism}

- In theory extremely important (Becken, S. (submitted). A Critical Review of Tourism and Oil. Annals of Tourism Research)

- Very little specific research in tourism

- Some recognition by stakeholders but little priority

- Very limited response by tourists, most likely to reduce spending on restaurants

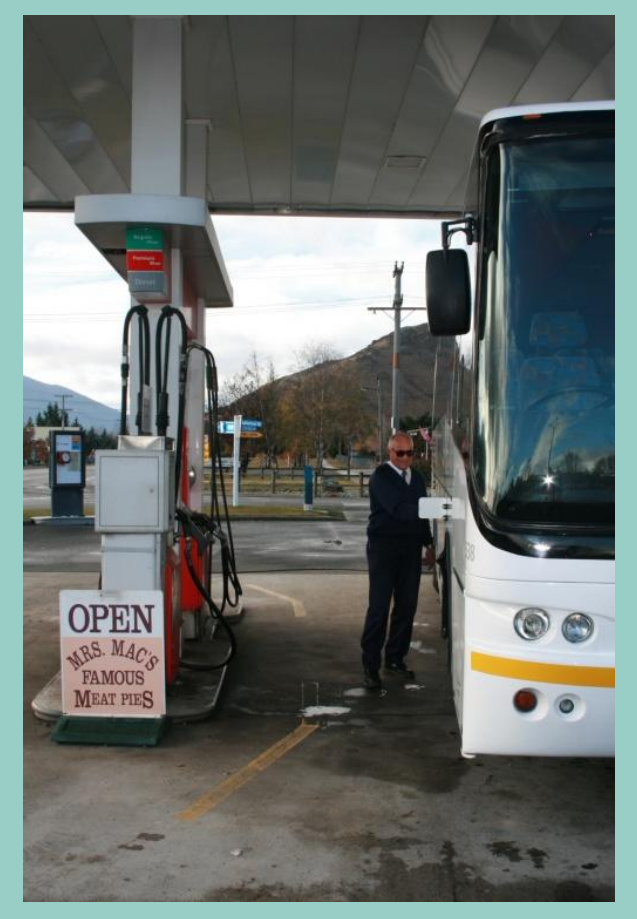

(Becken, S. \& Wilson, J. (2008). Environmental attitudes and fuel saving behaviour by KEA Campers Customers. LEaP Report 6. Lincoln University. Available http://www.leap.ac.nz) 


\section{Tourism demand for NZ}

- Oil prices affect macro economy and income

- Income is a key driver for tourism, esp. long haul

- Price effects (airfares)

- Distinguish oil-importing and exporting countries

Schiff, A. \& Becken, S. (2010). Demand Elasticities for NZ visitor arrivals price elasticity estimates for those segments where a statistically significant relationship could be established

\begin{tabular}{|l|l|l|}
\hline Segment & Price Measure & Price Elasticity \\
\hline South Korea & Total price & -1.75 \\
China FIT & Total price & -1.65 \\
Japan Tour & Total price & -1.55 \\
China Tour & OTG prices & -1.09 \\
Australia FIT VFR & Airfare & -1.05 \\
Germany all & Airfare & -0.87 \\
USA Tour & Total price & -0.78 \\
UK Holiday & Total price & -0.52 \\
Australia Tour & Airfare & -0.31 \\
USA FIT Holiday & Total price & -0.29 \\
Australia FIT Holiday & Airfare & -0.26 \\
\hline \multicolumn{2}{|l}{} \\
$\begin{array}{l}\text { Note: FIT means free independent traveller; Tour stands for tour group visitors; VFR means visiting } \\
\text { friends and relatives; for more information on the tourist segments please see Becken et al., 2008. }\end{array}$
\end{tabular}

Tourism Management.

friends and relatives; for more information on the tourist segments please see Becken et al., 2008.

\section{( Centre for Land Environment \& People




\section{Destinations within NZ}

- Constructed a 'distance model' (1997 to 2007)

- Only the propensity to travel by car for Australians and travel distance by car for British and Japanese tourists was significantly negatively affected by fuel prices.

- Apart from that other variables are more influential (e.g. length of stay, repeat visitation)

- Still possibility that more remote businesses are more vulnerable

(Becken, S. \& Schiff, A. (2010). Distance Models for New Zealand International Tourists and the Role of Transport Prices. Journal of Travel Research)

\section{()) Centre for Land




\section{Vulnerability of Products and Businesses}

- Vulnerability influenced by 1) Exposure, 2) Substitution options, 3) Market mix, 4) Diversification, 5) Geography, 6) Competition

- Energy makes up in the order of $5-10 \%$ of operating revenue (depending on business) (Becken, S. \& Carboni, AJ. (2008). Managing Energy Use in Tourism Businesses - Survey Results. LEaP Report 4. Lincoln University. http://www.leap.ac.nz)

- Avg savings potential in accommodation: $20 \%$

- Online Vulnerability Assessment Tool 


\section{CGE Model - whole-of-economy}

- Effects on overall economy rel. small

- Tourism effects substantial

- Differences in market segments (e.g. UK decreases substantially)

\begin{tabular}{|lr|}
\hline & $\begin{array}{r}100 \% \text { increase in } \\
\text { oil price }\end{array}$ \\
\hline Real GDP & $-2.3 \%$ \\
Labour force & $-1.3 \%$ \\
Real wage & $-6.7 \%$ \\
Total imports (value) & $1.9 \%$ \\
Total exports (value) & $0.1 \%$ \\
Tourism exports (value) & $-10.3 \%$ \\
Overall tourism & $-7.1 \%$ \\
consumption (quantity) & \\
Accommodation (quantity) & $-5.7 \%$ \\
Rental vehicles (quantity & $-14.7 \%$ \\
Domestic air transport & $-3.3 \%$ \\
(quantity) & \\
\hline
\end{tabular}




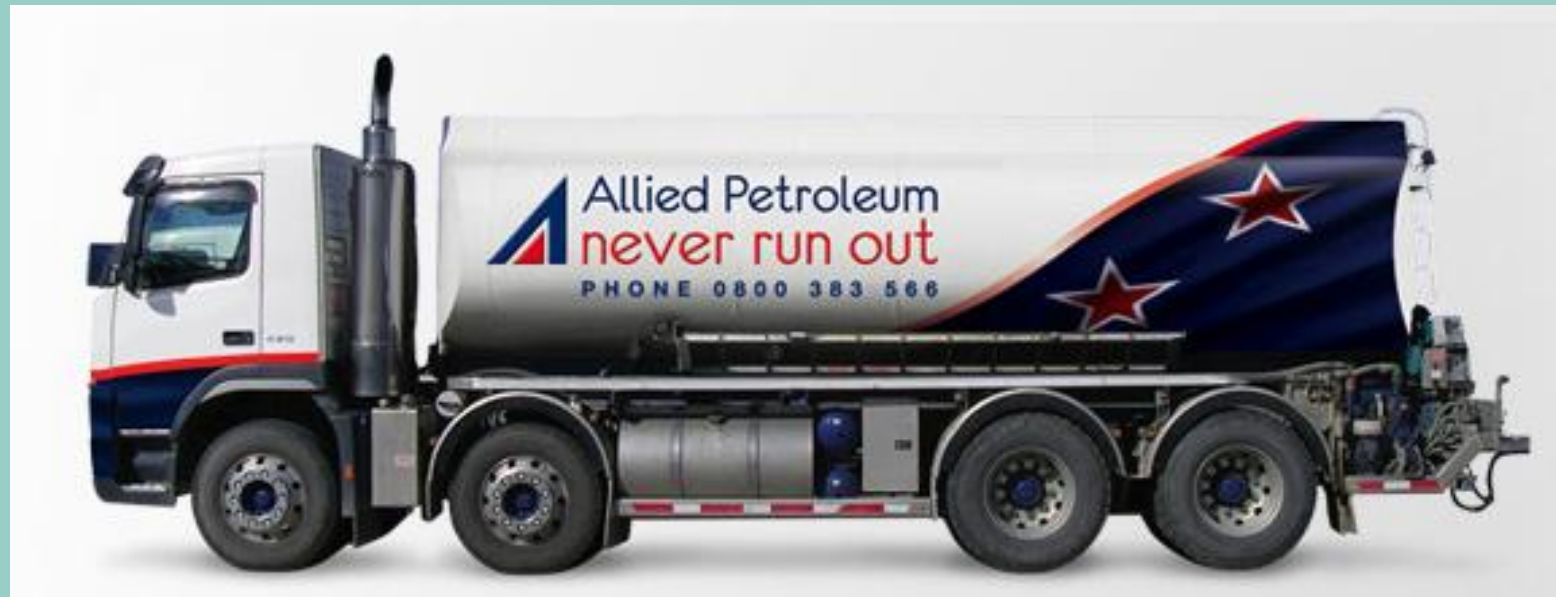
م) Centre for Land
Environment
LEAP
\& People
A Lincoln University Research Centre.
New Zealand's specialist land-based university 


\section{Conclusions}

- Increasing oil prices present a major risk for tourism

- Tourism is ill-prepared (not sufficiently aware of risks and implications)

- Oil, tourism and the global economy are intimately interwoven

- Inelastic behaviour provides buffer to some extent

- Some destinations, industries and segments are more vulnerable than others 


\section{Questions?}

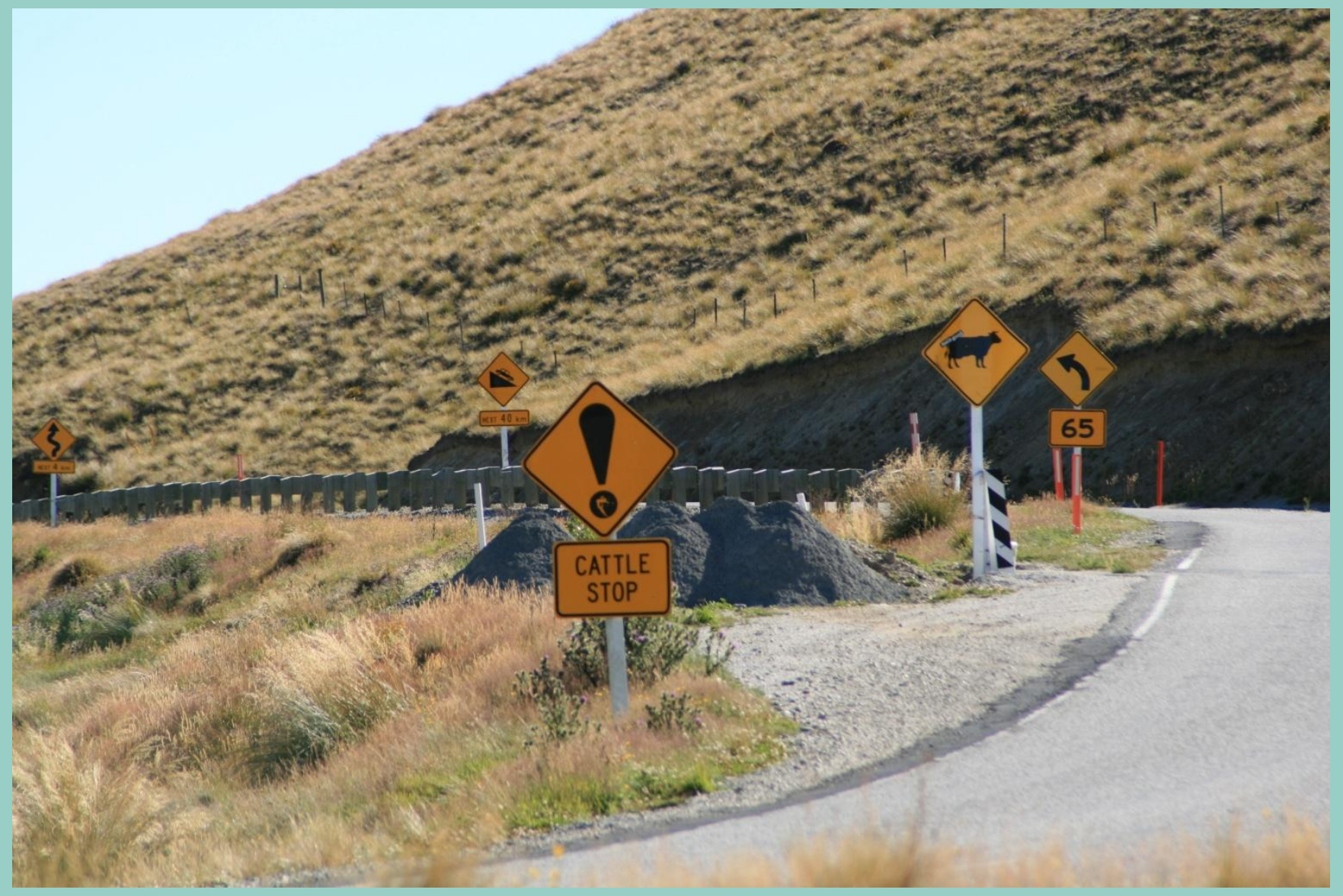
○) Eentre for Land
LEAP
\& People

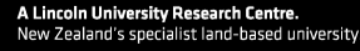

\section{Lincoln \\ 19 University}

